\title{
Geotourism from Fuente de Cibeles of Madrid. History, Building Stones and Quarries
}

\author{
Geoturismo de la Fuente de Cibeles de Madrid. \\ Historia, piedra de construcción y canteras
}

\section{DAVID MARTÍN FREIRE-LISTA*1,2}

${ }^{1}$ UTAD - Universidade de Trás-os-Montes e Alto Douro. Quinta de Prados. 5001-801 Vila Real, Portugal

${ }^{2}$ CGeo - Centro de Geociências da Universidade de Coimbra. Rua Silvino Lima. Universidade de Coimbra - Polo II. 3030-790 Coimbra, Portugal

*Autor de contacto: davidfreire@utad.pt

\section{Resumen}

La fuente de Cibeles de Madrid (España) representa a la diosa Cibeles sentada en un carruaje tirado por dos leones. Este conjunto escultórico fue tallado principalmente en mármol de Montesclaros (Toledo-España) entre los años 1777 y 1782 y a lo largo de su historia ha experimentado diversas modificaciones. En el año 1798 se instalaron dos surtidores zoomorfos, uno con forma de dragón y otro con forma de oso, tallados en la caliza de Colmenar de Oreja. La fuente se trasladó unas decenas de metros en el año 1895. En esa obra se elevó todo 
el conjunto escultórico y se instalaron dos putti de mármol de Carrara en la parte de atrás del carruaje, ampliando la superficie del promontorio rocoso sobre el que se asienta el conjunto escultórico. La fuente adquirió su forma actual en el año 1968; cuando se añadieron dos vasos escalonados de granito.

A partir de la Fuente de Cibeles y su principal piedra de construcción, el mármol de Montesclaros, se creó una ruta geoturística. Una descripción exhaustiva, las fases de construcción y alteraciones de la fuente se presentan para completar la ruta por Montesclaros y zonas cercanas. De esta forma, se crean alternativas que diversifican las opciones turísticas convencionales de la ciudad de Madrid. Además, se aportan datos científicos sobre las canteras históricas y el mármol que forma parte de la emblemática fuente.

\begin{abstract}
Fuente de Cibeles of Madrid (Spain) represents Cybele goddess sitting on a carriage drawn by two lions. This sculptural set was carved in Montesclaros (Toledo-Spain) marble between 1777 and 1782. The sculptural set has experienced some modifications throughout its history. Two zoomorphic water-spouts carved in Colmenar de Oreja limestone, one in the shape of a dragon and another one in the shape of a bear, were installed in 1798. In 1895, the fountain changed of location, and two putti of Carrara marble were installed on the back of the fountain, expanding the rocky surface promontory on which the sculptural set stands. Two tiered basins made of granite were added in 1968, when the fountain acquired its current form.

A geotouristic route was created based on Fuente de Cibeles and its main building stone, Montesclaros marble. An exhaustive description of the fountain was made, and its construction history was reviewed to elaborate the route. In this way, alternatives that diversify the conventional tourist options of the city of Madrid are presented. In addition, scientific data on historical quarries and the marble that forms part of the emblematic fountain is provided.

Key words: Geoheritage, Montesclaros marble, petrography, Heritage stones, Cybele

Palabras clave: Patrimonio Geológico, mármol de Montesclaros, petrografía, Cibeles
\end{abstract}




\section{INTRODUCTION}

The concept of heritage has evolved in recent decades. At present, the definition of heritage has been extended to include natural, historical and cultural elements. For this reason, UNESCO created new World Heritage categories that include cities, industrial, cultural landscapes and routes (Matthews and Grant-Smith 2017, Portillo et al. 2018). In addition, the creation of Geoparks, a territory encompassing one or more geological sites of scientific importance, stimulates geotourism, a form of tourism that focuses on geology and landscape (Dongying et al. 2012, Singh and Subhash 2013, Anand 2014). Geoparks can also include archaeological, natural and cultural sites and are generally located in sparsely populated areas, far from big cities, which are still the focus of the largest number of tourists (Ahluwalia 2006, Saluja and Anand 2017, Citiroglu et al. 2017, Dowling and Newsome 2017). Geosites and their geodiversity, natural or human-modified, is a sustainable source of resources for villages, which can develop geotouristic routes that spread out tourism from big cities to other locations (Hall and Zeppel 1990a, 1990b, Newsome and Dowling 2010, Manríquez et al. 2019).

Traditional building stones are key cultural tourist attractions around the world (Primavori 2015, Norum and Mostafanezhad 2016). They are an important cultural and social focus of cities and their conservation promotes intergenerational equity by preserving cultural capital for the benefit of future generations (Misirlisoy and Günc 2016, Zoghlami et al. 2017). The care and conservation of monuments are essential to protect the identity and to guarantee the successful future of cities (Soini and Birkeland
2014). Traditional building stones are part of a city's tangible and intangible heritage (Harrowell 2016), and their historical quarries should be recognized as valuable assets (Siegesmund and Török 2011, Bednarik et al. 2014, Pereira and Marker 2016), as they constitute identifying and differentiating traits particular to each city (Kramar et al. 2014, Freire-Lista and Fort 2018). With this objective, the Heritage Stones Subcommision, an International Union of Geological Sciences (IUGS) subcommission, promotes natural and heritage stones (Cooper et al. 2013) with the purpose of using original stones in the restoration and conservation, especially of monuments and historical buildings, as well as to preserve their historical quarries, emphasizing the importance of Heritage Stones in the preservation of World Heritage Sites (Hughes et al. 2013, Almeida and Begonha 2014, Costa 2014, De Wever et al. 2016).

Spain is the third country with most UNESCO World Heritage Sites, although none of them is currently located in the city of Madrid. However, this city receives more than 10 million visitors each year. The axis formed by Paseo del Prado and Parque del Retiro is a candidate for recognition as a cultural landscape by UNESCO. The designed cultural landscape includes gardens, parks and monumental assemblages built for aesthetic and functional reasons.

The possible recognition of Paseo del Prado and Parque del Retiro as a cultural landscape by UNESCO is a challenge for urban heritage conservators and tourism managers. Urban planning, conservation and tourism should be conducted through a multiplicity of both theoretical and methodological perspectives that require an interdisciplinary vision (Pendlebury et al. 2009, Van Oers 2010). 
The main traditional building stones of Madrid have been presented to the candidacy of Global Heritage Stone (Fort et al. 2015, Freire-Lista et al. 2015, Freire-Lista and Fort 2016) to guarantee their use in restoration, and to conserve their historical quarries. The aim of this study is the creation of a geotouristic route based on Montesclaros marble, the main building stone of Fuente de Cibeles at Paseo del Prado of Madrid. An exhaustive description of the fountain is made, and its construction history is reviewed to elaborate the route through the Montesclaros area, where lime kilns and historical quarries are located, together with a broad geoheritage. In this way, alternatives that diversify the conventional tourist options of the city of Madrid are presented.

\section{FUENTE DE CIBELES DESCRIPTION}

The monumental sculptural set of Fuente de Cibeles was designed by the architect Ventura Rodríguez. It was built between 1777 and 1782 in neoclassical style to form part of Salón del Prado, originally conceived by José de Hermosilla y Sandoval following the model of Piazza Navona of Rome (González Serrano 1990). That is, Salón del Prado's layout has three aligned fountains: Fuente de Cibeles at the northern end on Paseo de Recoletos, in the semicircle on the corner of calle de Alcalá, next to Buenavista Palace and facing south towards Salón del Prado; Fuente de Apolo (or Fuente de las Cuatro Estaciones), in the center; and Fuente de Neptuno, located at the southern end (Fig. 1).

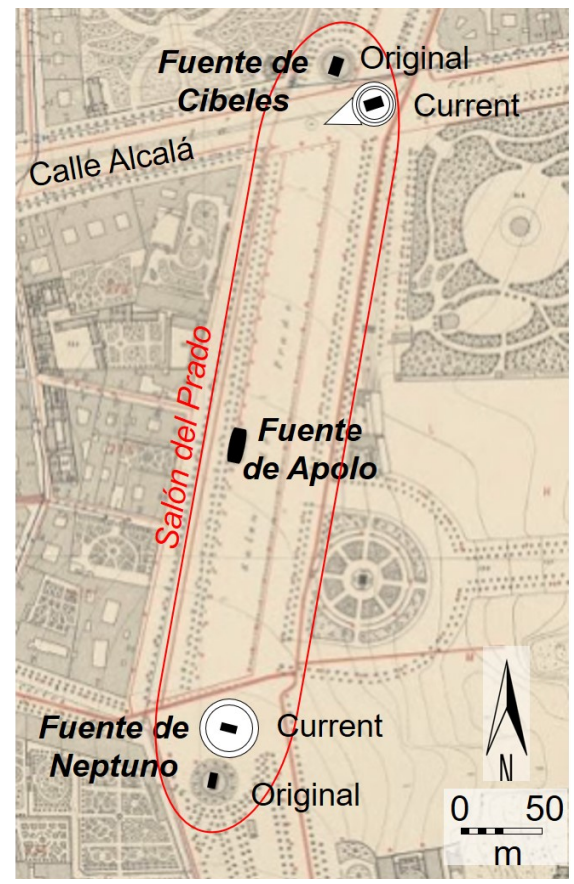

Figure 1. Salón del Prado of Madrid plan with the original and current location of Cybele, Apollo and Neptune fountains 
Cybele is a goddess of nature and symbol of the earth, agriculture and fertility. In Fuente de Cibeles (Fig. 2), she is sitting on a throne with her feet crossed and is dressed in classical Greek style. She wears sandals and a tunic, the chiton. A mantle, the himation, covers the tunic and part of the throne's back left side. She wears over her hair a double-crenelated mural crown with 5 towers and 5 gates in each level. This mural crown symbolizes the support of Cybele to Madrid. Her hair is parted in the middle and is collected under the mural crown into a loose bun that unravels as it drops over her neck and right shoulder.

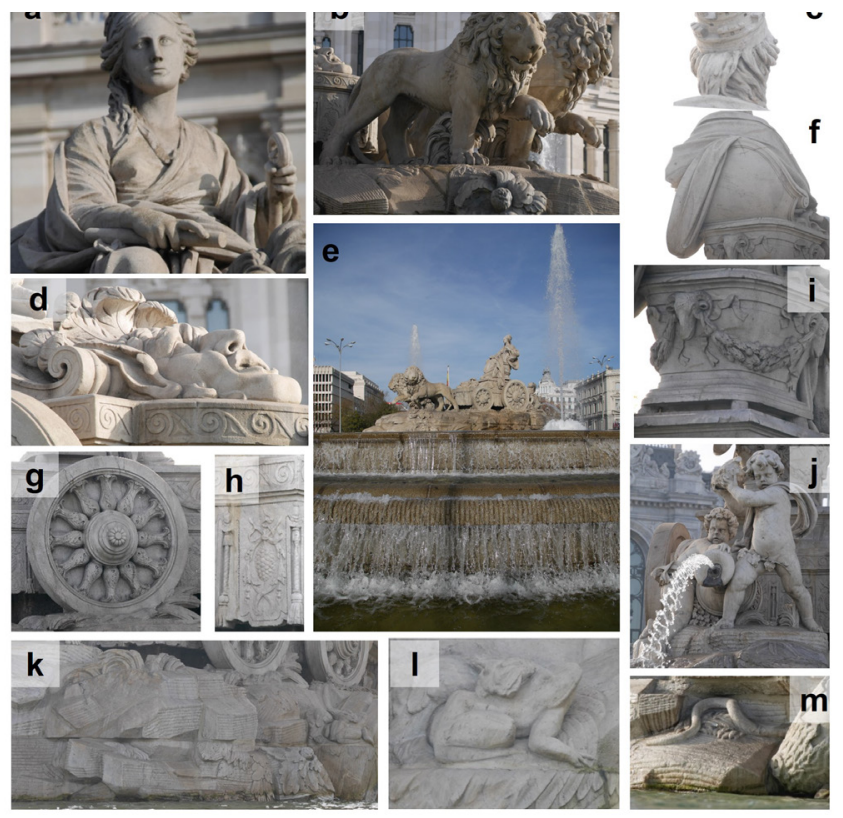

Figure 2. Fuente de Cibeles (Madrid) a: Goddess Cybele wears a mantle, the himation, that covers her tunic, the chiton. Cybele holds in her right hand lying on her lap a sceptre, or baton. In her left hand she holds the keys of the city; b: Two male lions facing opposite sides with their left legs raised; c: Goddess Cybele wears a double-crenelated mural crown over her hair; $d$ : Attis is represented at the moment of his transformation into a pine tree by the mask laying at the feet of goddess Cybele, in the front of the carriage; e: General view of Fuente de Cibeles. In the foreground are the three circular tiered basins of granite; f: Back of the back of the throne and right armrest; g: Rear wheel of the carriage with twelve spokes in the shape of vegetable buds. $\mathrm{h}$ : The frieze's decoration is allusive to the death of Attis. It consists of a repeating pattern of pinecones, tree branches, bands, and flowers alternating with whips with tassels at their ends; i: Two rams' heads adorn the throne, one in the back and another one in the right side. A ram's horn can be seen in the left side of the throne. The head of this ram is covered by Cybele's himation; $\mathrm{j}$ : Two putti are placed on the rocky promontory behind the carriage. The one on the left kneels holding a lying amphora. The one on the right is standing, with a vine branch between his spread legs, stretches his arms over the other putto, and holds a conch shell with both hands; $\mathrm{k}$ : The promontory simulates a rocky surface decorated with plant motifs, a frog under the rear right wheel (l), and a snake in the back right, next to a felled tree trunk (m) 
Cybele holds in her right hand lying on her lap a sceptre, or baton, as a symbol of her power and dignity. In her left hand she holds the keys of the city, resting them on top of the himation that covers the left armrest of the throne on which she is sitting.

The heads of two rams adorn the throne, one in the back and another one towards the front of the right side. A ram's horn can be seen in the left side of the throne. The head of this ram is covered by Cybele's himation. From the horns hang garlands of flowers and fruits held by floating bands that line the sides. The ram's head refers to Zeus, as a symbol of the criobolium ceremony, characteristic of the Cybele cult. This rite consisted in the capture and sacrifice of a ram so that its blood was poured over an initiate.

The throne has four cylindrical feet and rests on a rectangular platform measuring approximately $2 \times 1.5 \mathrm{~m}$. The platform's sides are decorated with plant motifs and two volutes towards the front, between which lays a mask from whose mouth originally emerged the main water-spout. The platform rests on a processional carriage with a rectangular ground plan and a curved front $(2 \times 4 \mathrm{~m}$ approximately). The upper perimeter of the carriage is decorated with a strip of linked spirals from which hangs a valance sculpted as a frieze.

The frieze's decoration consists of a repeating pattern of pinecones framed by two upside-down tree branches. A band ties the two branches and the stem of the pineapple together. Two flowers hang from the end of each branch. Whips with tassels at their ends in memory of the punishment to Attis are carved on each side.

The front wheels of the carriage are smaller than the rear wheels. They have 10 and 12 spokes respectively, in the shape of vegetable buds. The axle of the wheels is topped by a rosette of twelve petals and a central hemispherical button.

Two putti, two infants just dressed in a mantle that flows over their shoulders and waist, are placed behind the carriage. The one on the left kneels holding a lying amphora. This amphora is profusely decorated with geometric motifs and water flows from it. The one on the right is standing, with a vine branch between his spread legs, stretches his arms over the other putto, and holds a conch shell with both hands.

Attis, raised by a ram, was in love with goddess Cybele and had sworn allegiance to her. But his adoptive parents sent him to marry the daughter of the king of Pessinus. Just when the nuptial song was being chanted, Cybele appeared and Attis went crazy and emasculated himself (cut his genitals). Attis died bleeding near a pine tree. Violets sprang from his blood. Cybele condemned her lover for having been unfaithful. However, she later regretted it, and prevented Attis' body from rotting by turning him into a pine tree. Cybele condemned him to drive his carriage forever. Attis is represented at the moment of his transformation into a pine tree by the mask laying at the feet of goddess Cybele, in the front of the carriage. His mouth functioned as a spout that sprayed water above the two lions that pull the carriage. These lions also represent two mythological lovers: Hippomenes and Atalanta. Hippomenes fell in love with Atalanta and conquered her with the help of Aphrodite, who showed him the trick of the golden apples. Atalanta, consecrated to Artemis (goddess of hunting, wild animals, virginity and maidens) was known for her hunting skills and challenged her suitors to a race to gain her love. Hippomenes participated in the 
race to win the love of Atalanta. He asked for help from Aphrodite, who gave him some gold apples to throw in front of Atlanta during the race, so that Atalanta would stop to pick them up. In this way Hippomenes arrived first at the finishing line and won the hand of Atalanta. Both lovers consummated their love in a temple dedicated to goddess Cybele. In the face of such sacrilege, the enraged goddess made Zeus turn the two lovers into lions and punished them to pull her carriage forever and not look at each other anymore. Two male lions facing opposite sides with their left legs raised are represented in the fountain.

The sculptural set rests on an oval promontory approximately $10 \mathrm{~m}$ long by $5 \mathrm{~m}$ wide. This promontory simulates a rocky surface decorated with plant motifs, a frog under the rear right wheel, and a snake (whose head is at present broken) towards the rear left side of the rocky promontory, next to a felled tree trunk. This structure occupies the centre of three circular tiered basins. The inner and topmost one is approximately $19 \mathrm{~m}$ in diameter and pours water over the middle basin, which is approximately $23 \mathrm{~m}$ in diameter. The middle basin in turn pours water over the outermost and biggest basin, which has a diameter of approximately $30 \mathrm{~m}$ and lies at ground level.

\section{METHODOLOGY}

A visual inspection was performed on the stones of Fuente de Cibeles. Five marble samples were extracted from the currently functioning San Pedro de Alcántara quarry at Montesclaros (40.076002, -4.929253) and another five samples from a historical quarry at Montesclaros (40.078169, -4.933098). These samples were cut and polished. In addition, two thin sections were made and characterized under a polarized light microscope Olympus BX 51 equipped with a digital DP coupled camera (6 V/2.5 $\AA$ ) and Olympus DP-Soft software (version 3.2). A mosaic was constructed with 20 microphotographs and an approximate surface area of $150 \mathrm{~mm} 2$.

A visual stone inspection was made of the zoomorphic water-spout sculptures, which were part of Fuente de Cibeles, and which are currently conserved in San Isidro. Los Orígenes de Madrid Museum.

In order to write the chronology of the construction history of Fuente de Cibeles, a meticulous documentary search was carried out in historical archives. A large number of historical photographs of Biblioteca $\mathrm{Na}$ cional de España, among others, was studied. Geological maps and local residents have been consulted in situ to design the geoturistic route through the marble quarries and the lime kilns of Montesclaros.

\section{CONSTRUCTION OF FUENTE DE CIBELES}

The architect Juan de Villanueva wrote on the Fuente de Cibeles plan in 1777 that the goddess, the carriage, the lions and the plant motifs of the rocky promontory would be sculpted in Montesclaros marble. The rocky promontory and the base of the basin in Redueña dolostone (the latter one crossed out).

The public announcement requesting bidders to transport the stones was published and posted in the busiest places of Madrid on June 7th, 1779. This advertisement had the aim of finding transporters for the stones that were being extracted from the quarries of Montesclaros, (province of 
Toledo), and of Redueña (province of Madrid) for the fountains that would be built in Salón del Prado of Madrid.

As the Villa de Madrid (City of Madrid) did not reach an agreement with any of the bidders for transportation, Ventura Rodríguez announced the detail of the transportation prices and weight of the stones in mid-July 1779 . In this announcement he specified that the marble should be white and from Montesclaros.

Antonio Moreno de Negrete, manager of the Salón del Prado works, was responsible for awarding the bid. There were several bidders and after considerable adjustments, Pedro de la Paliza won the tender to transport the marble from Montesclaros to Madrid. The shipment of the marble began on June 2 th, 1780. The caravan took 92 days to reach a construction yard located in the Prado de San Jerónimo, where the stones were carved. Just to transport the heaviest stone $(7184 \mathrm{~kg}$ ), it took 25 days and 9 pairs of oxen. The stonecutter Domingo Pérez was in charge of extracting the stones for the Salón del Prado fountains (Albarrán 1986).

Several sculptors participated in the carving of the Fuente de Cibeles sculptural set. Roberto Michel carved the lions. Francisco Gutiérrez Arribas carved the goddess Cybele and the carriage wheels, and Miguel Ximénez carved the carriage's frieze.

The fountain was completed in October 1782. It was at ground level, protected by
20 bollards of granite from Sierra de Guadarrama, traditionally called Piedra Berroqueña (Fort et al. 2013). The bollards were cylindrical with two smooth borders at their ends and topped with a rosette of twelve petals and a central button at the top (Fig. 3 a, b, c and d). A cobblestones flint pavement measuring ten feet wide was placed around it in December of the same year to facilitate water access to draft animals and to people (González Serrano, 1990).

Juan de Villanueva designed in 1791 two zoomorphic water-spouts for the basin, a dragon to the right and a bear to the left of the goddess Cybele, animals that referred to Madrid's coat of arms. Alfonso Giraldo Bergaz Jr. was the sculptor and the waterspouts began to operate in 1798 , when Domingo Pérez finished the pedestals on which they were settled (González Serrano 2007). They supplied water for human consumption through bronze pipes inserted into their mouths. In addition, there were manual water pumps on the basin, and draft animals drank from the basin (Fig. $3 \mathrm{a}$ and b). The Canal de Isabel II, a network of hydraulic infrastructures created to supply water to the city of Madrid, entered into service in 1858 , and consequently the fountain was no longer used to supply drinking water. The zoomorphic water-spouts and the bollards were removed in 1862. After this, a castiron fence was installed around the fountain (Fig. 3 c, d, and e, Fig 4).

Figure 3. Fuente de Cibeles in its original location. a: Fragment of the painting by Ginés Andrés de Aguirre, 1785. Puerta de Alcalá is seen in the background, to the left side of goddess Cybele, and a horse is drinking from the basin; b: Engraving by Isidro Velázquez, 1788. Goddess Cybele is looking towards Salón del Prado and horses are drinking; c: Engraving by David Roberts, 1835. Bear-shaped water-spout; d: Photograph, 1853. Bearand dragon-shaped water-spouts, three manual water pumps, barrels of water for human consumption and the peripheral bollards; e: Photograph, 1864. The original water-spout came out through a pipe in the mouth of the mask and was divided into four jets. f: Photograph, 1891. Fountain without zoomorphic water-spouts, and with a perimeter cast-iron fence. An asterisk indicates the position of the fountain at present; g: Photograph, c. 1870 . The trunks of felled trees and the snake on the rocky promontory are in their original position. 

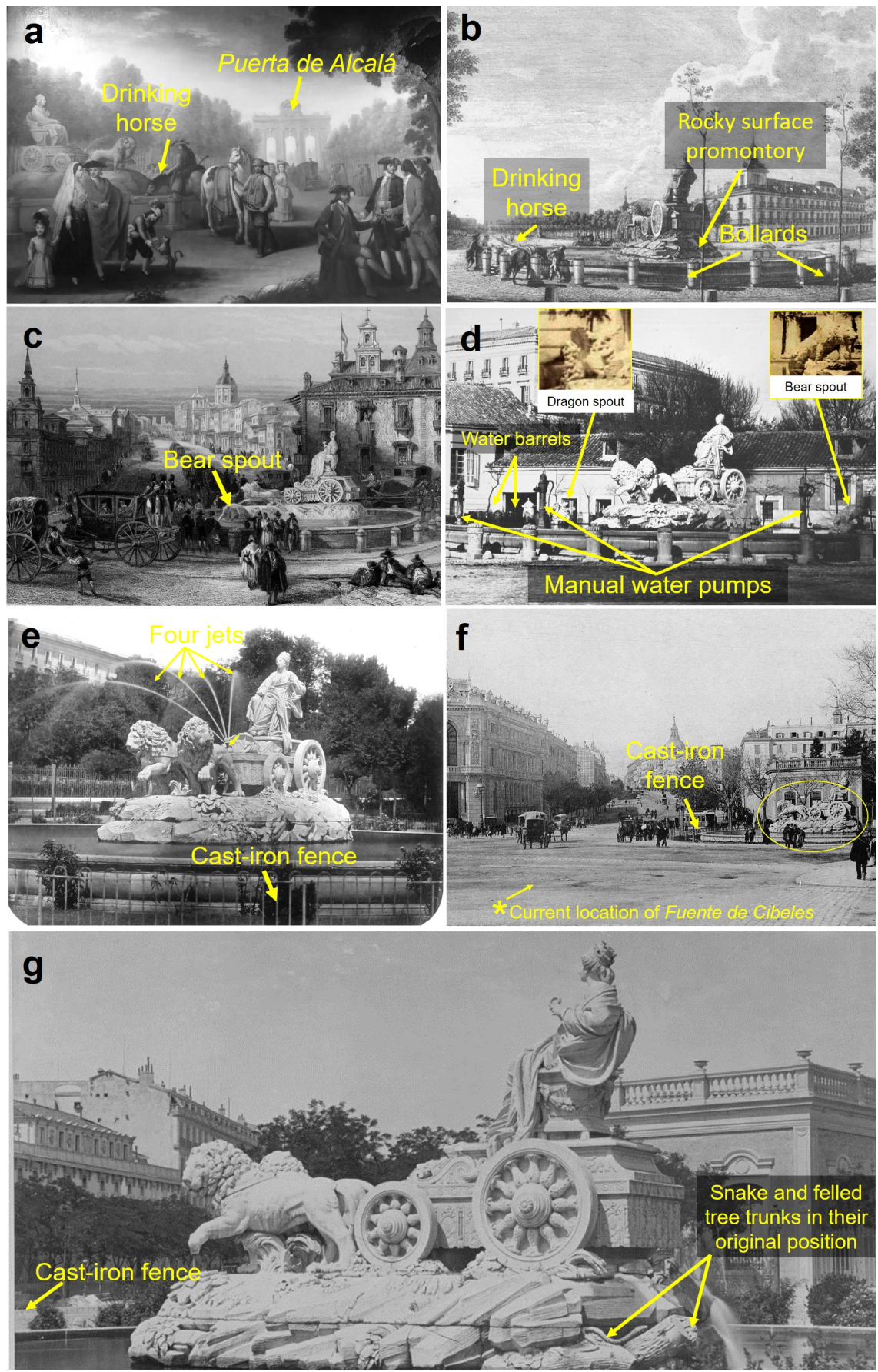


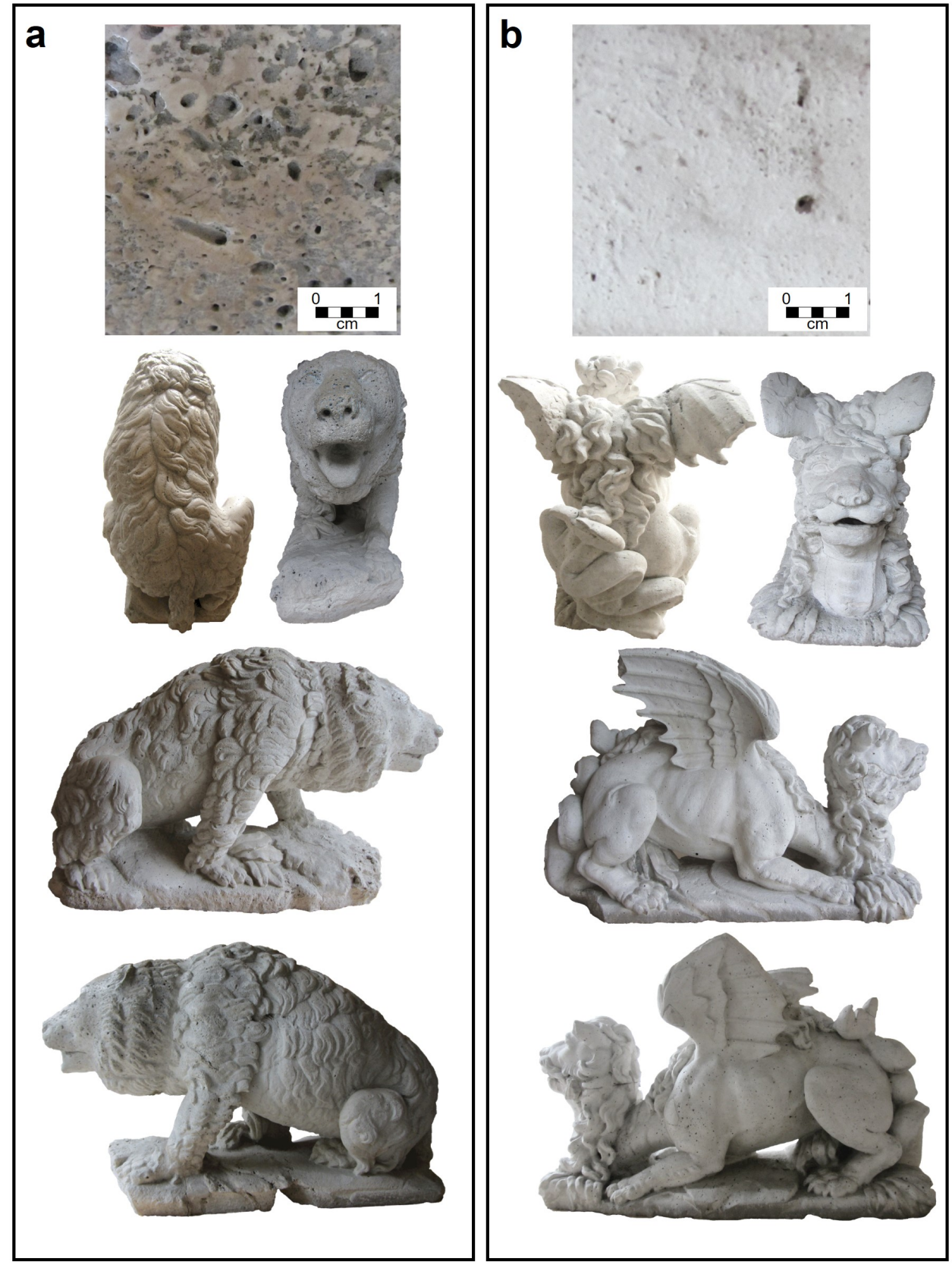

Figure 4. Zoomorphic water-spouts sculpted in limestone and preserved in San Isidro. Los Orígenes de Madrid Museum. a: Bear; b: Dragon. 
The municipal architect José López Salaberry designed the project to transfer the monument from its initial location to the centre of a circular island or sidewalk in the current Plaza de Cibeles (with the goddess facing west towards calle de Alcalá), and the fountain set was raised and repositioned in 1895 (Fig. 1). The sculpture of goddess Cybele rose two meters and sixty centimetres from the pavement. The granite basin was placed on top of a circular platform of four granite steps on a circular sidewalk. Eight equidistant rectangular cuboid blocks of limestone were inserted in the first three steps of the platform, on top of the sidewalk (Fig. 5 a). The rocky surface promontory on which the carriage rests was also raised with a granite base covered with flint rocks (Fig. 5 b), whereupon the original base of the basin disappeared (González Serrano, 1990). The rocky promontory was enlarged towards the back of the carriage to install two putti. The putto on the left, the one that pours water from the amphora, was carved by Miguel Ángel Trilles, the one on the right, standing and holding the conch shell, by Antonio Parera Saurina (Fig. 5 b). These putti were sculpted in Carrara marble (López de Azcona 2002, Murru et al. 2018).
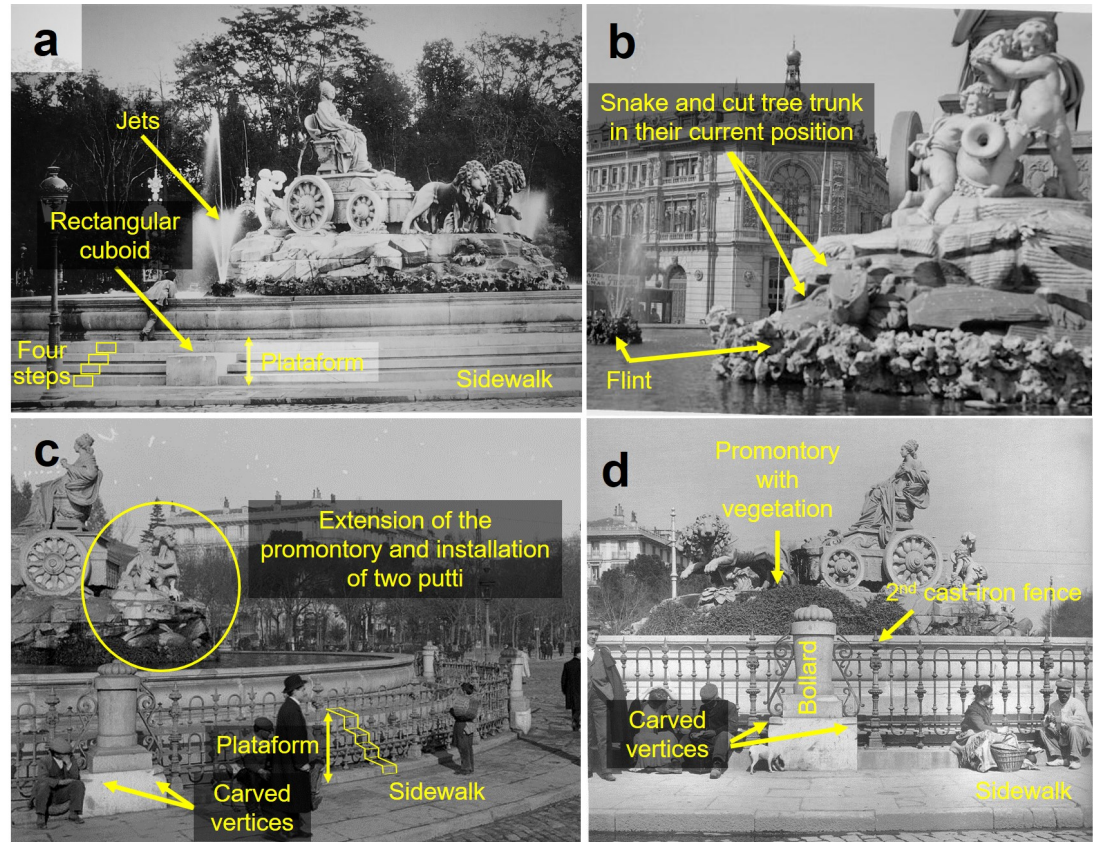

Figure 5. Fuente de Cibeles elevated and enlarged after it was transferred to its current location. a: Photograph, c. 1895. Sidewalk and platform on which Fuente de Cibeles was placed composed by four steps of granite with eight limestone cuboids; b: Photograph, c. 1906. Central and parabolic peripherals ornamental jets (left) with flint base, flint rocks and putti (right); c: Photograph, c. 1906. Sidewalk and the four steps on which the fountain was installed. Granite bollards with a base of limestone, cast-iron perimeter fence, and two putti on the extension of the rocky surface promontory to the back side; d: Photograph, c. 1906. Eight granite bollards and a cast-iron perimeter fence were placed on limestone bases and first step respectively. Vegetation covers part of the rocky promontory 
The snake and the felled tree trunks of the rocky promontory were moved backwards at that time to their current position under the putto that holds the amphora (Fig. 6). Two groups of ornamental jets, with the highest vertical central jet surrounded by smaller parabolic ones were installed on the sides of the goddess (Fig. 5 a). The waterspouts of these jets were also coated with flint rocks. A few years after the repositioning of the fountain, a new cast-iron perimeter fence was installed around the entire fountain. The new fence had more ornamentation than the previous one, was fixed to the lowest step and attached to eight bollards of granite installed on the eight rectangular cuboids of limestone, whose upper vertices were carved for such purpose (Fig. $5 \mathrm{c}$ and d).
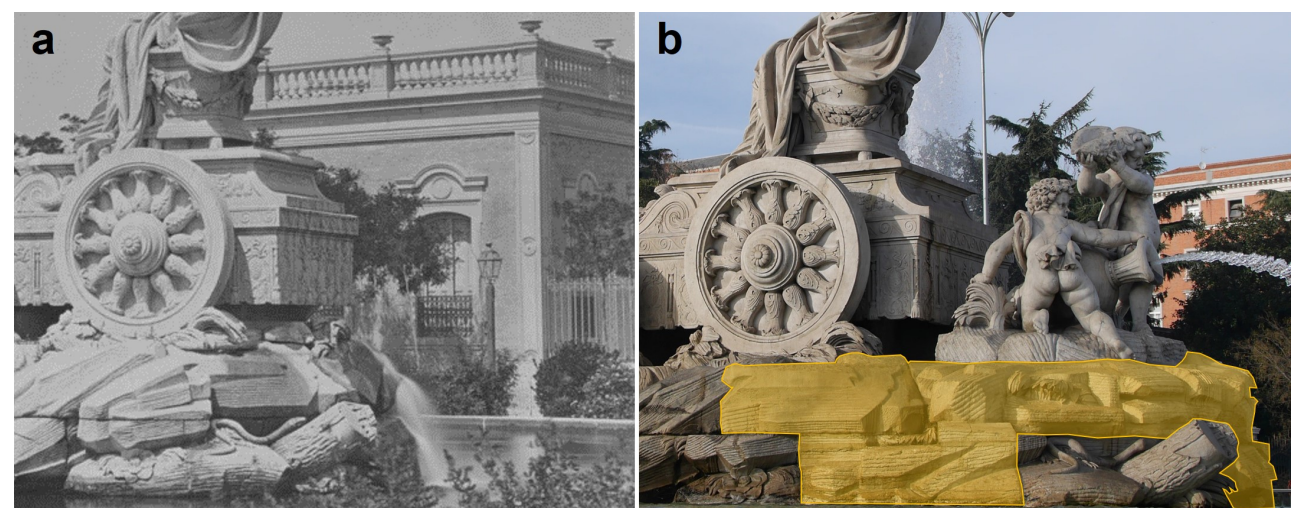

Figure 6. Detail of the back rocky promontory. a: Photograph, c. 1870. The trunks of felled trees and the snake on the rocky promontory are in their original position. b: Photograph, 2018. Detail of the pieces added (yellow) and moved (trunks of felled trees and the snake) in the back of the rocky promontory.

An arm, the keys, the sceptre and the nose of goddess Cybele were damaged during the Second Republic in 1931 and were restored in the same year. The left lion was damaged during the beginning of the Spanish Civil
War by the impact of projectiles (Fig. 7 a). It lost the snout and suffered damage to the left front leg and tail, so the fountain was protected with sandbags and bricks between 1937 and 1939 (Fig. 7 b and c). 

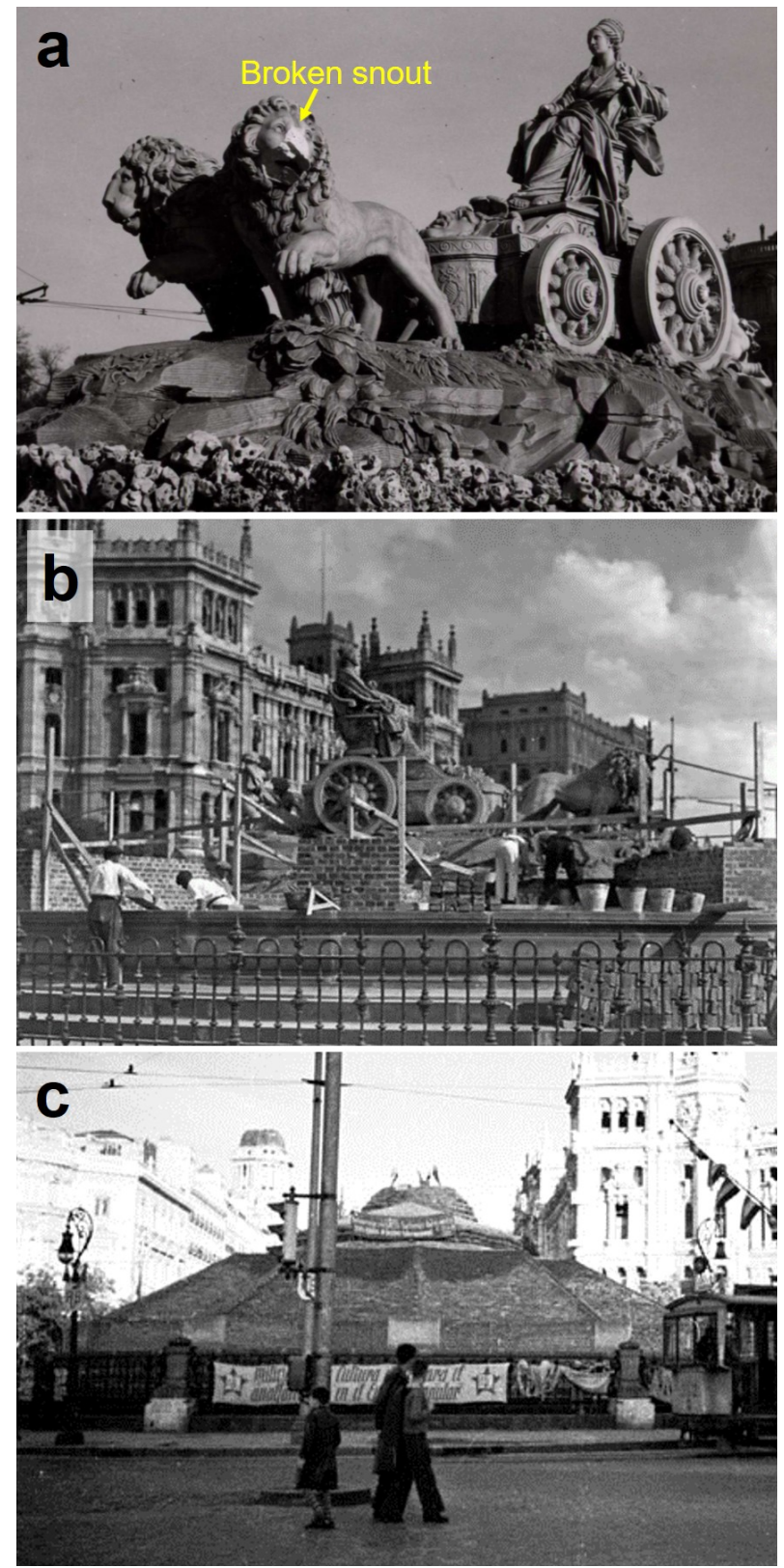

Figure 7. Fuente de Cibeles during the Spanish Civil War. a: Photograph, 1936. Lion with damaged snout; b: Photograph, 1937. Fuente de Cibeles began to be covered under a pyramid of sandbags and bricks on July 3th, 1937; c: Photograph, between 1937 and 1939. Protected Fuente de Cibeles 
After the Spanish Civil War, an interim restoration was made. The snout was reconstructed with plaster and fastened with metal staples and the cast-iron perimeter fence was removed. Ornamental jets were added around the rocky promontory and on the interior perimeter of the basin. The two groups of lateral jets were replaced by two new groups of higher jets whose spouts were no longer coated with flint rocks (Fig. $8 \mathrm{a}$ and $\mathrm{b}$ ). A lighting system bordering the jets and behind the carriage were installed for night illumination of the fountain (Fig. $8 \mathrm{c}$ ). In addition, the external perimeter of the fountain basin was landscaped (Fig. 8 d).

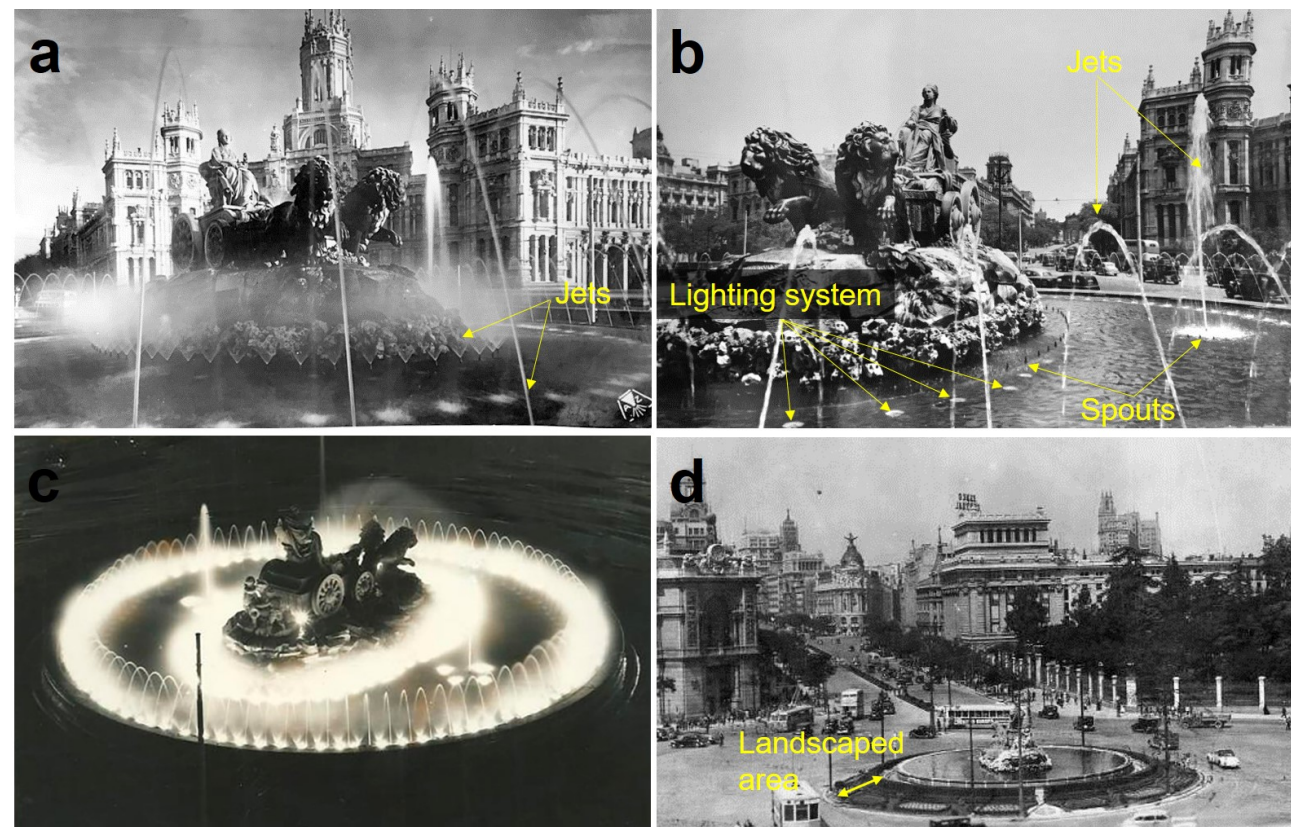

Figure 8. Fuente de Cibeles after the Spanish Civil War; a: Photograph c. 1941. Ornamental jets; b: Photograph, c. 1941. Ornamental jets. Vertical jet without flint rock covering the water-spouts; c: Photograph, c. 1960.Night lighting; d: Photograph, c. 1941. Landscaped area around the fountain

Fuente de Cibeles gained its current appearance in 1968, with the addition of two granite basins with cascading water from the upper basin to the new external basins (Fig. $2 \mathrm{e})$. The flint rock covering the base of the rocky promontory (Fig. 5, Fig. 7 a, Fig. 8) was also removed.

The fountain was refurbished in 1980, and works were carried out to build a bronze replica that was presented as a gift to the capital of Mexico. An integral restoration was carried out in 1981. The joins were cleaned up. For the reintegration of the broken pieces (the face of the left lion, the nose and the lip of the putti on the right side, part of the left rear wheel and its spokes, among other damaged elements) resin with marble dust was used. Cybele recovered the big toes of the feet, the index finger and the sceptre of the right hand, the thumb and the ends 
of the key held by the left hand and some deteriorated parts of the mantle (González Serrano, 1990).

A vandalism act covered the sculpture with phosphorescent paint in 1992, and it was cleaned that same year. In 1994, the left hand of goddess Cybele was mutilated during the celebrations of a victory of the Spanish national football team and was replaced that same year. This hand was again mutilated and replaced by a new one in 2002. This new hand was also made from Montesclaros marble, from San Pedro de Alcántara quarry.

The most recent restoration works were performed in 2016. Biological crust and cracked mortars were removed, and unstable elements were secured. Water-repelling treatment was applied in the last phase of the restoration.

\section{HISTORICAL QUARRIES OF MONTES- CLAROS MARBLE (TOLEDO-SPAIN)}

Montesclaros is located approximately $140 \mathrm{~km}$ from Fuente de Cibeles of Madrid and approximately $15 \mathrm{~km}$ north of Talavera de la Reina (Toledo). The geology, numerous vestiges of historical quarries and old lime kilns (Casas et al., 2020) in this area have great geotouristic interest, comparable to other places in the world (Barroso et al. 2018, Romana and Farabollini 2018).

Montesclaros marble emerges in the Gredos Complex, in a band approximately $11 \mathrm{~km}$ long and up to $1 \mathrm{~km}$ wide, in NNWSSE direction, which goes from the vicinity of the Tiétar River, to the north, to the Guadyerbas River, to the south, between the villages of Hontanares and Montesclaros, where these are high-grade regional metamorphic materials (Fig. 9).

To the S and SW of Montesclaros, among the granite, there is an alternation of phyllites, calco-schists and dolomitic marbles, which shapes the landscape and gives a great geodiversity to the area. The marbles are very coarse to coarse-grained (crystal size up to $5 \mathrm{~mm}$ ) and predominantly white, white-bluish in color. In addition, there are gray, blue-gray, cream, pink and cream marbles. The existence of these light-colored marbles explains the toponym Montesclaros, which means light (claro) mountains (montes). These marbles have been exploited since Roman times, as a Roman road passed through the vicinity of Montesclaros, and Roman marble tombs have been found in the vicinity of the village. 


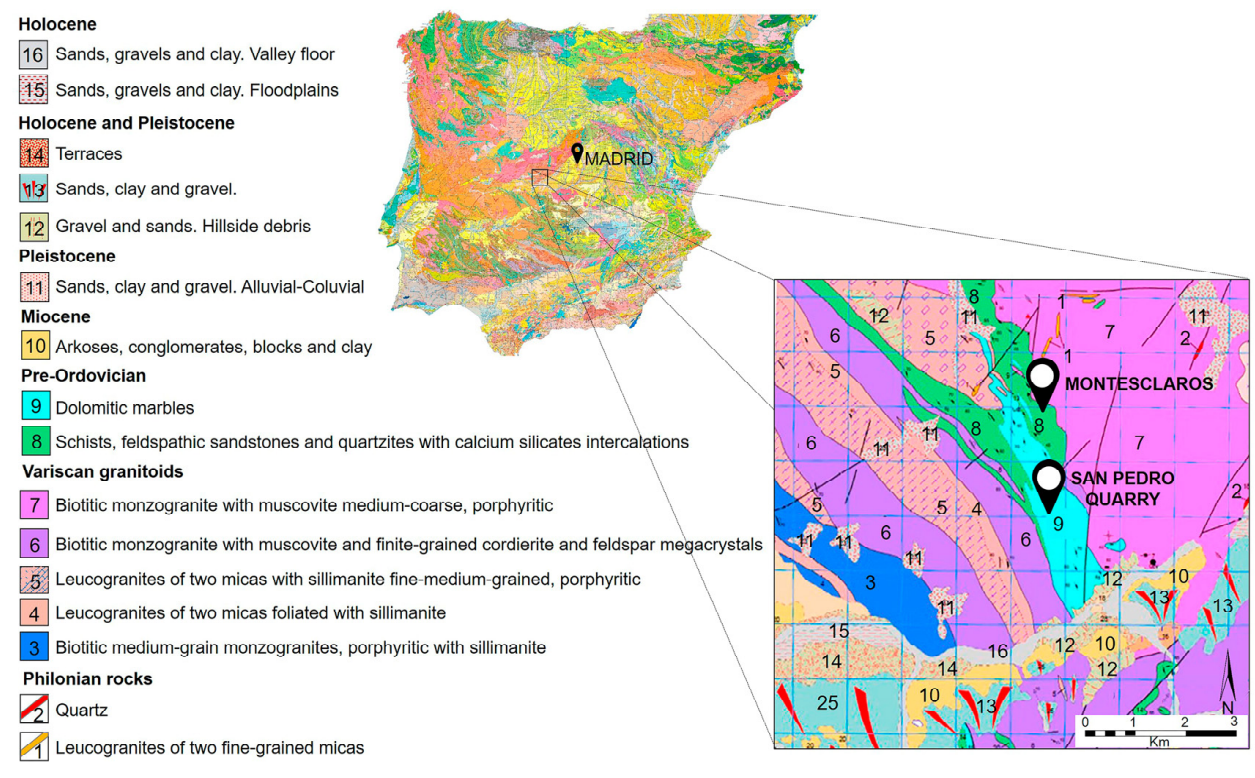

Figure 9. Geological map of the Montesclaros area (Geological map of Spain. IGME, Navalón, 601. 15-24)

The geomorphological features are mostly determined by the hydrographic system, which flows in subparallel valleys. The hills are elongated and are generally gently modeled. In the southern slope of Cerro de Don Pedro there are numerous trenches, lime kilns and quarries, most of them semicovered with vegetation. Nowadays there is a quarry in operation, San Pedro de Alcán- tara (40.075916, -4.928995), which exploits white-bluish marble as crushed aggregates. Petrographically, this dolomitic marble has crystals visible to the naked eye with coarse equigranular blasts and granoblastic texture. The blasts boundaries are very sinuous, and microcrystals fill cracks and blast boundaries (Fig. 10). The porosity is very low, 1.06\% (López de Azcona 2002). 

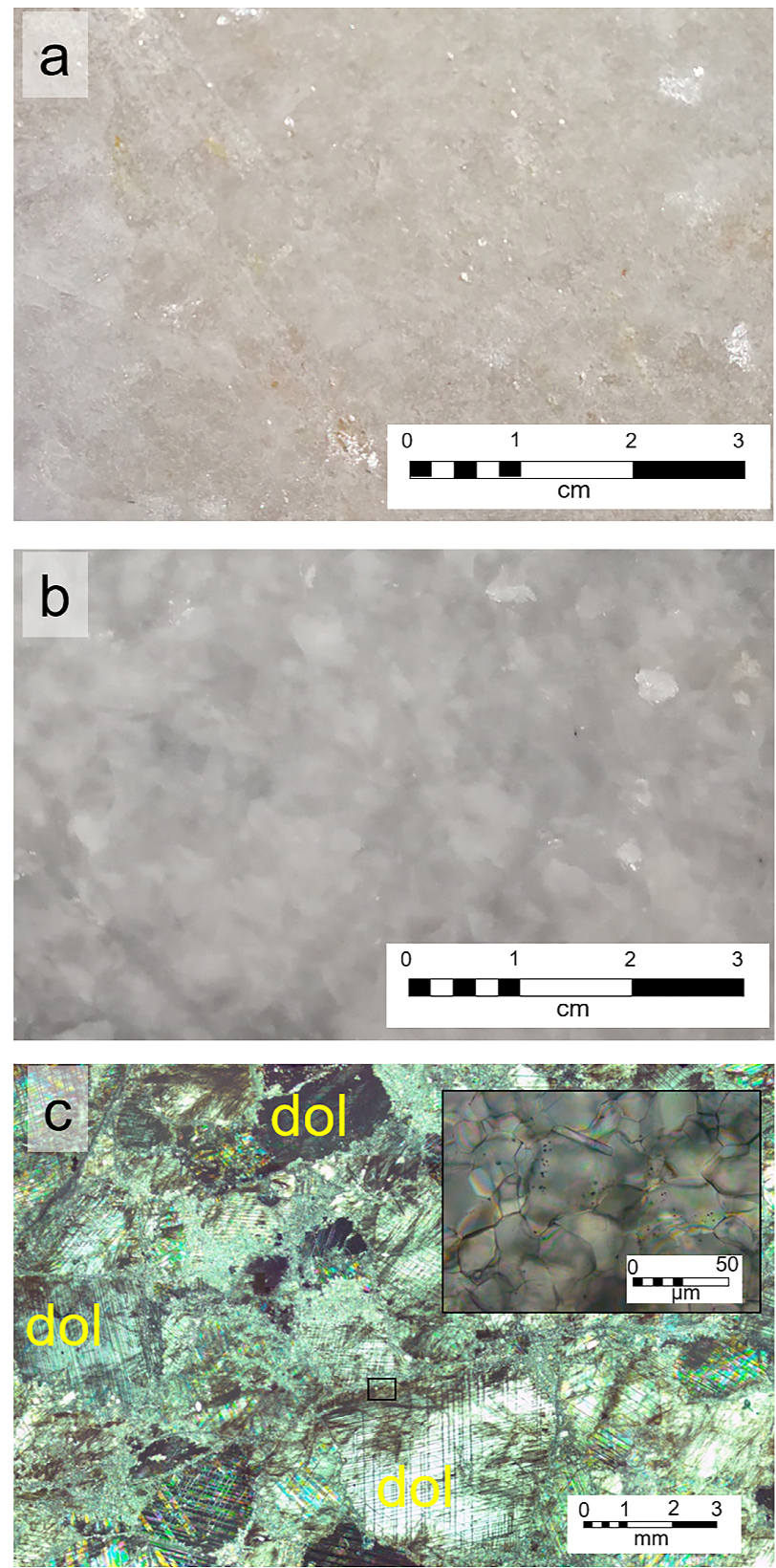

Figure 10. Montesclaros marble a: Polished naked-eye sample taken from the historic Montesclaros quarry (whitish color); b: Polished naked-eye sample taken from the currently functioning Montesclaros quarry (bluish color); c: Mosaic of microphotographs of Montesclaros marble 


\section{GEOTURISTIC ROUTE}

Montesclaros geology, nature and culture offer an opportunity to enhance local geoheritage. This geotouristic route is approximately $7.5 \mathrm{~km}$ long. It has low difficulty and can be done both walking and cycling. The route is divided into three clearly differentiated sections (Fig. 11). The first section is urban and passes through Montesclaros village, with stopping points at its monuments and historical buildings. The second section goes along a path through meadows with trees. This is a human-modified landscape where one can find trenches and lime kilns. The third section reaches the marble quarries and goes through and area with a greater density of trees.

The geotouristic route begins at Parque de las Eras, located in the northern outskirts of Montesclaros village, on the road to Hontares. Opposite to the entrance of the park, a large tiled signpost reads "Montesclaros Cuna de Cibeles y Neputuno" (which means "Montesclaros Craddle of Cybele and Neptune"), reminding the visitor of the link between Montesclaros village and the two fountains (Fig. 11 a). An old iron artifact on wheels, old machinery from a historical marble quarry has been installed at Parque de las Eras (Fig. 11 b). To the south, in the center of Monteclaros is the parish church of Virgen de los Remedios (Fig. $11 \mathrm{c}$ ). It was built with granite ashlars and masonry in 1552. This temple has a single vaulted nave and a presbytery with a pointed vault. The church has been renovated several times, more significantly in the mid-eighteenth century. Another Montesclaros monument is the Gothic whipping post, which is located in the main square. The whipping post is carved in granite and sits on top of five steps. The cylindrical shaft has seven courses of ashlars. The Mendozas' coat of arms (lords of this Village) is sculpted in the top of the shaft. The shaft also has a later inscription from the 19th century. The pinnacle is simple with a decorative band and is very deteriorated and topped with a metal rod (Fig. $11 \mathrm{~d}$ ).

Talavera or Los Caleros path is to the south of Montesclaros village. On this path, the first lime kilns (Fig. 11 e) are located approximately half a kilometer away from the whipping post. Lime kilns are wells with a depth of up to five meters and a maximum width of about five meters. The wood to heat the ovens was introduced through a small opening in the bottom (Goreti Margalha et al. 2008). In the inner part of the well, above the opening, there is a circular ledge about $20 \mathrm{~cm}$ wide to place the marble in vaulted form so that the heat is distributed homogeneously.

Continuing the path, less than a kilometer away, is the Renaissance church of San Sebastián (17th century). It has a square floor plan, with granite walls and a semicircular archway. A granite Gothic cross with the coat of arms of the Mendozas' stands next to the church (Fig. $11 \mathrm{f}$ and g).

Hundreds of trenches and up to twenty lime kilns can be found along the Talavera path (Fig. 9 h, i and j). Traditionally these kilns were named by the locals, for example: tío Juan, de la Viña, el Chaparro Alto, el Charcón, el Nuevo, el Chico, Cosa Mala, Casilla, Coscoja, and los Industriales.

Following the path approximately $1.5 \mathrm{~km}$ further south, at coordinates (40.077602, -4.936073), the path forks, and the path to the left (eastward) leads to the historical marble quarries. The first quarry that can be seen is on the right margin of the 
path, approximately $400 \mathrm{~m}$ from the fork, at coordinates $(40.078141,-4.933181)$ (Fig. 9 1). Approximately $70 \mathrm{~m}$ away from this quarry, also on the right side of the path, there is another historical quarry where white marble was extracted (40.078545, -4.932205). Continuing the path another $300 \mathrm{~m}$ further, there is one more historical quarry (40.079590, -4.931326) (Fig. 9 m). At the end of the path there is an intersection (40.080396, -4.930359). The path to the right leads to the San Pedro de Alcántara quarry that is currently in operation (Fig. $11 \mathrm{n}$ ), and the path to the left leads back to Montesclaros village, approximately $3.5 \mathrm{~km}$ away.
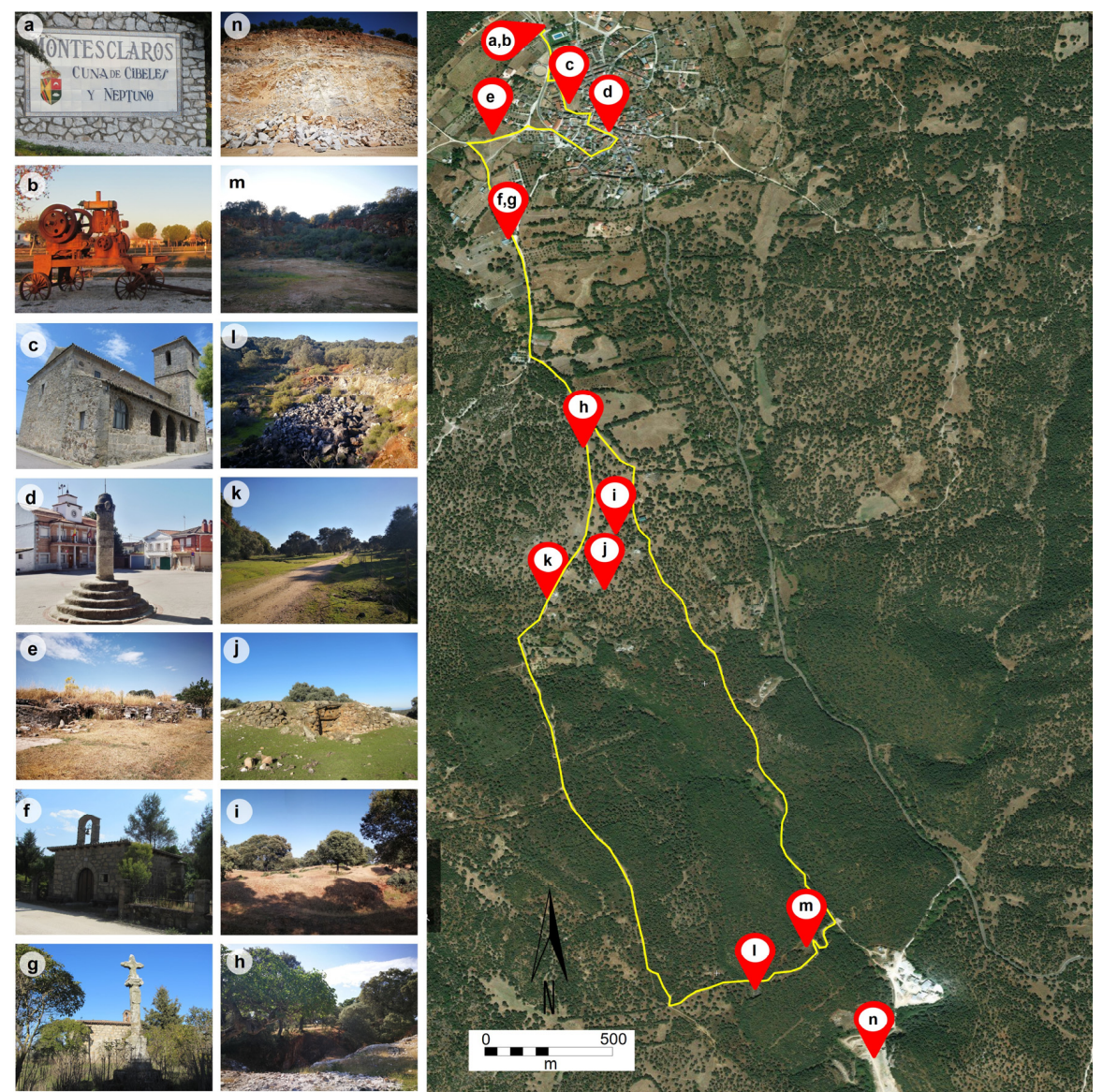

Figure 11. Geotouristic route through the historic lime kilns and quarries of Montesclaros. a: Tiled signpost that indicates the link between Montesclaros village and Fuente de Cibeles; b: old machinery from a historical marble quarry; c: Parish church of Virgen de los Remedios d: Gothic whipping post in Montesclaros main square; e: First lime kilns on Talavera path; f: Church of San Sebastián; g: granite Gothic cross with the coat of arms of the Mendozas; $h$ and $\mathrm{i}$ : Trenches and marble quarries; $\mathrm{j}$ : Lime kiln; $\mathrm{k}$ : General view of the path. Landscape with meadows and holm oaks; 1: Historical marble quarry; m: Historical marble quarry; n: San Pedro de Alcántara marble quarry (currently in operation) 
This geotouristic route can be suppplemented with a visit to Santuario de San Pedro de Alcántara (1775), declared a National Historic-Artistic Monument in 1972, to observe the use of Montesclaros marble. This sanctuary is in the town of Arenas de San Pedro (Ávila), taking road N 501 from Montesclaros northwest towards Hontanares, $21 \mathrm{~km}$ away from Montesclaros.
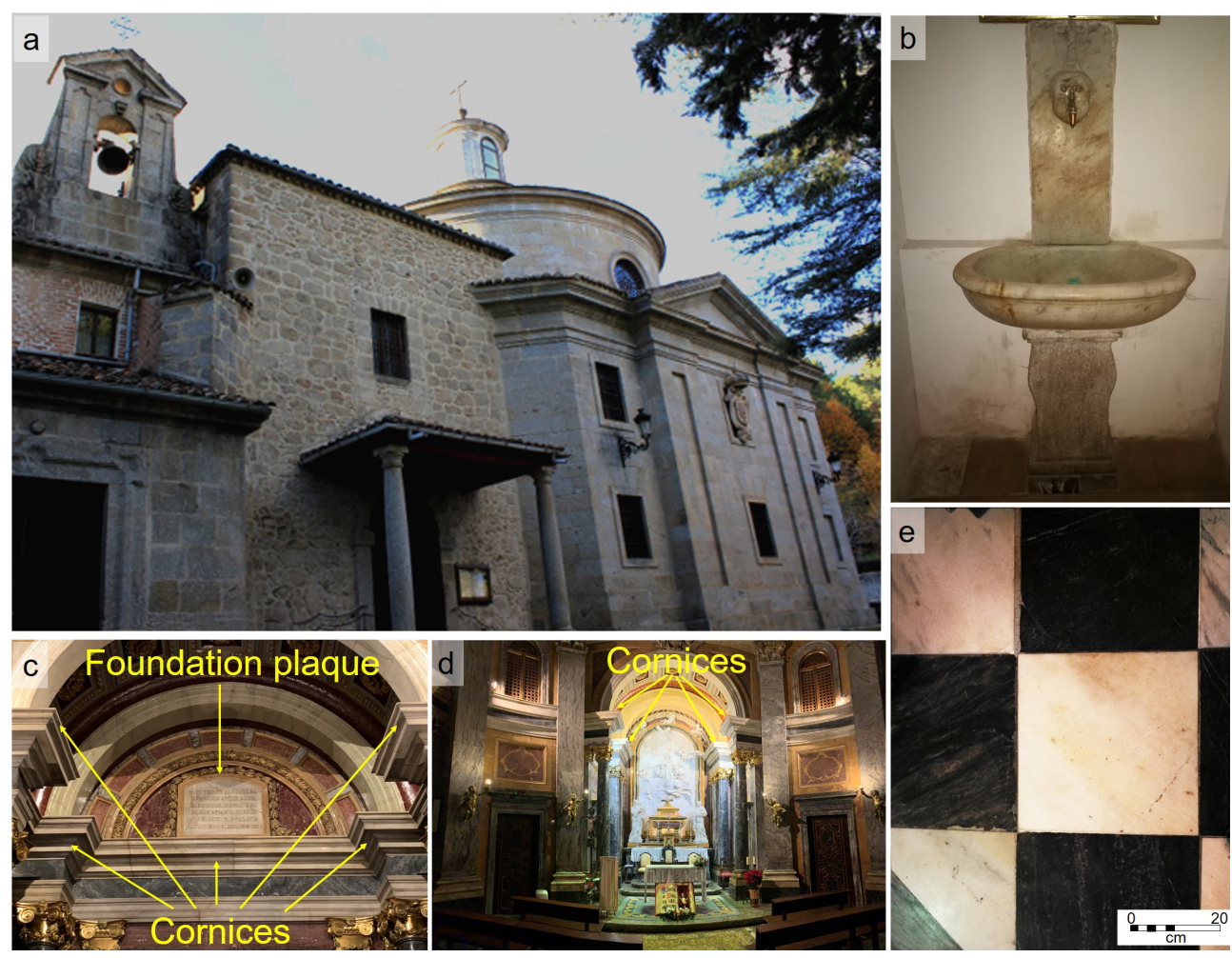

Figure 12. Santuario de San Pedro de Alcántara. a: West facade of the Sanctuary, on the right side the Royal Chapel can be observed, b: Basin carved with Montesclaros marble in the sacristy; c: Interior of the Royal Chapel where the founding plaque and cornices sculpted in Montesclaros marble can be seen; d: Interior of the Royal Chapel, cornices carved in marble from Montesclaros; e: Paving of the Royal Chapel, the white slabs are made with Montesclaros marble.

OBSERVATIONS ON THE BUILDING STONES OF FUENTE CIBELES

Some authors have erroneously attributed the quarries of Redueña dolostone, a town located approximately $60 \mathrm{~km}$ north of Madrid, as the source of the building stones of Fuente de Cibeles. This misunderstanding may be due to two issues. As it has been 
indicated previously, in the plan of Fuente de Cibeles, Ventura Rodríguez wrote that the rocky promontory and the basin base would be made of Redueña stone. However, this phrase is crossed out, so it is possible that Ventura Rodríguez changed his mind due to the difficulty of finding large blocks in the Redueña quarries (Cámara et al. 2011, Fort 2008, Freire-Lista and Fort 2017a).

Another possible cause of the error is that the book Viaje de España, written by Antonio Ponz Piquer in 1781, states that the quarries of the Salón del Prado fountains are near Redueña. However, the stonecutter Domingo Pérez indicates that the stones that were brought for Fuente de Cibeles (the stones for the two lions, all the stones of basin base, and the stones for the carriage) were brought from the quarries of San Pedro de Alcántara of Montesclaros (Albarrán 1986). However, it is true that Fuente de Apolo and the four fountains of Plaza Murillo, all of them in Salón del Prado, have been sculpted with Redueña dolostone (Freire-Lista and Fort 2017b).

Limestone was not initially intended to be the stone used in the bear- and dragonshaped water-spouts. A document dated September 27th, 1791 indicates that they would be sculpted in Montesclaros marble (González Serrano 2007), but the zoomorphic water-spouts were sculpted in Colmenar de Oreja limestone (Fig. 4).

As mentioned above, Montesclaros marble has different colors depending on the outcrop's position. This study has determined that Ventura Rodríguez used the whitest marble extracted from Monteclaros's historic quarries, which are nowadays in disuse. The marble found in the currently functioning quarry has a white-bluish color, while the marble used in Fuente de
Cibeles and in Santuario de San Pedro de Alcántara is whiter with a slight alteration of yellowish color (Fig. 2, Fig. 10, and Fig. 12). Therefore, any proper restoration work should select marble with the same petrographic and aesthetic characteristics as the original one to preserve the integrity of the monuments.

\section{ACKNOWLEDGEMENTS}

This study was funded by Fundação para a Ciência e a Tecnologia of Portugal (FCT) CEECIND/03568/2017. Thanks to Eduardo Salas Vázquez, Director of San Isidro. Los Orígenes de Madrid Museum, and to María Victoria López Hervás, Head of the Exhibition, Cultural Action and Dissemination Division of the same museum for their collaboration and availability for the taking of photographs and observation of the construction materials of the bear and dragon water-spouts.

Thanks to Francisco José Marín Perellón, director of Imprenta Municipal Artes del Libro of Madrid for his collaboration and availability of documentation.

Thanks to the Franciscan monks of Santuario de San Pedro de Alcántara in Arenas de San Pedro for their willingness to examine the elements built with white Montesclaros marble.

\section{REFERENCES:}

Ahluwalia, A.D., 2006. Indian geoheritage, geodiversity: Geosites and geoparks. Current Science 91 (10)

Albarrán, E.R., 1986. La Cibeles y Neptuno vinieron de Montesclaros. 167pp. ISBN 10: 8439866380 / ISBN 13: 9788439866381 
Almeida, A., Begonha, A., 2014. Contribution of Portuguese two-mica granites to stone built heritage: the historical value of Oporto granite. In: Pereira D, Marker B, Kramar S, Cooper B and Schouenborg B (eds) Global Heritage Stone: Towards International Recognition of Building and Ornamental Stones. Geological Society, London, Special Publications, 407. http://dx.doi.org/10.1144/SP407.16

Anand, S., Saluja, V., Singh, R.B., 2014. Varkala as a National Geopark of India: Geographical realities. International Journal of Geoheritage, 2 (1), 65-81

Barroso, C.E., Oliveira, D.V., Ramos, L.F., 2018. Vernacular schist farm walls: materials, construction techniques and sustainable rebuilding solutions. Journal of Building Engineering 15, 334-352. https://doi.org/10.1016/j.jobe.2017.12.001

Bednarik, M., Moshammer, B., Heinrich, M., et al., 2014. Engineering geological properties of Leitha Limestone from historical quarries in Burgenland and Styria, Austria. Eng Geol 176, 66-78. https:// doi.org/10.1016/j.enggeo.2014.04.005

Cámara, B., de los Ríos, A., Urizal, M., et al., 2011. Characterizing the microbial colonization of a dolostone quarry: implications for stone biodecay and response to biocide treatments. Microb Ecol 62, 299-313. https://doi.org/10.1007/s00248011-9815-x

Casas, L., Auguet, C., Guasch-Ferré, N., Gómez-Paccard, M., Prada, J.L., Pitarch Martí, A., Badia, M., Sanjurjo-Sánchez, J., Díaz, M., Menchon, J., 2020. Archaeomagnetic study of a limekiln in the Les Ferreres Roman aqueduct, World Heritage Site of Tarraco. Archaeological and Anthropological Sciences 12, 212. https://doi.org/10.1007/s12520-020-01175-2
Citiroglu, H.K., Isik, S., Pulat, O., 2017. Utilizing the Geological Diversity for Sustainable Regional Development, a Case Study-Zonguldak (NW Turkey) Geoheritage 9(2). https://doi.org/10.1007/ s12371-016-0196-X

Cooper, B.J., Marker, B.R., Thomas, I.A., 2013. Towards International Designation of a Heritage Dimension Stone Key Eng Mater. 548, 329-335. https:// doi.org/10.4028/www.scientific.net/ KEM.548.329

Costa, A., 2014. Natural stone in the built heritage of the interior of Brazil: the use of stone in Minas Gerais. In: Pereira D, Marker B, Kramar S, Cooper B, Schouenborg B. (eds) Global Heritage Stone: Towards International Recognition of Building and Ornamental Stones. J Geol Soc (London, UK) 407, 253-261. http://dx.doi.org/10.1144/SP407.13

De Wever, P., Baudin, F., Pereira, D., Cornée, A., Egoroff, G., Page, K., 2016. The importance of Geosites and Heritage Stones in Cities. Geoheritage 9(4), 561-575. https://doi.org/10.1007/s12371016-0210-3

Dongying, W., Wilson, J., Richardson, L.L., Murphy, C., Min, W., Changming, L., 2012. Towards Sustainable Development. Recommendation of Actions for Geoparks. J Geogr Sci 22(6), 1149-1150. https://doi.org/10.1007/s11442-0120988-0

Dowling, R.K., Newsome, D., 2017. Geotourism Destinations - Visitor Impacts and Site Management Considerations. Czech Journal of Tourism, 6(2), 111-129. https://doi.org/10.1515/cjot-2017-0006

Fort, R., Fernandez-Revuelta, B., Varas, M.J., et al., 2008. Effect of anisotropy on Madrid-region Cretaceous dolos- 
tone durability in salt crystallization processes. Mater Constr 58, 161-177. http://dx.doi.org/10.1016/j.conbuildmat.2015.07.087

Fort, R., Alvarez de Buergo, M., PérezMonserrat, E.M., et al., 2013. Evolution in the use of natural building stone in Madrid, Spain. Q J Eng Geol Hydrogeol 46, 421-429. https://doi.org/10.1144/ qjegh2012-041

Fort, R., Varas-Muriel, M.J., Alvarez de Buergo, M. et al., 2015. Colmenar Limestone, Madrid, Spain: considerations for its nomination as a Global Heritage Stone Resource due to its long term durability. J Geol Soc (London, UK) 407, 121-135. https://doi.org/10.1144/ SP407.8

Freire-Lista, D.M., Fort, R., Varas-Muriel, M.J., 2015. Alpedrete granite (Spain). A nomination for the "Global Heritage Stone Resource" designation. Episodes. 38 (2), 106-113.

http://hdl.handle.net/10261/118159

Freire-Lista, D.M., Fort, R., 2016. The Piedra Berroqueña region: candidacy for Global Heritage Stone Province status. Geoscience Canada 43 (1), 43-52. https:// doi.org/10.12789/geocanj.2015.42.076

Freire-Lista, D.M., Fort. R., 2017a. Stone provenance and conservation of the Trinitarias Descalzas of San Ildefonso convent, Madrid (Spain). Ge-Conservación 1(11), 25-33

Freire-Lista, D.M., Fort, R., 2017b. Historical quarries, decay and petrophysical properties of carbonate stones used in the historical Center of Madrid (Spain). AIMS Geosciences 3(2), 284-302. https://doi.org/10.3934/geosci.2017.2.284

Freire-Lista, D.M., Fort, R., 2018. Historical city centres and traditional building stones as heritage: the Barrio de las Letras, Madrid (Spain). Geoheritage 1-15. https://doi.org/10.1007/s12371-0180314-z

González-Sampériz, P., Valero, B.L., Moreno, A., Jalut, G., García-Ruiz, J.M., Martí, C., Delgado, A., Navas, A., Otto, T., Dedoubat, J.J., 2006. Climate variability in the Spanish Pyrenees during the last $30.000 \mathrm{yr}$ revealed by the $\mathrm{El}$ Portalet sequence. Quaternary Research 66, 38-52. https://doi.org/10.1016/j. yqres.2006.02.004

González Serrano, P., 1990. La Cibeles, nuestra Señora de Madrid ISBN 10: 8478120815 ISBN 13: 9788478120819. (Ed) Ayuntamiento de Madrid.

González Serrano, P., 2007. Un oso y un dragón, "okupas" jubilados de la fuente de Cibeles, ahora residen en el Museo de San Isidro. Ilustración de Madrid: revista trimestral de la cultura matritense 5, 43-4

Goreti Margalha, M., Appleton, J., Carvalho, F., Veiga, R., Santos Silva, A., de Brito, J., 2008. Traditional Lime kilns Industry or Archeology? Conference paper HMC08 Historical Mortars Conference Characterization, Diagnosis, Conservation, Repair and Compatibility.

Hall, C.M., Zeppel, H., 1990a. Cultural and heritage tourism: the new grand tour? Historic Environment 7(3/4), 86-98

Hall, C.M., Zeppel, H., 1990b. History, Architecture, Environment: Cultural Heritage and Tourism Journal of Travel Research 29, 54-55

Harrowell, E., 2016. Looking for the future in the rubble of Palmyra: Destruction, reconstruction and identity. Geoforum 69, 81-83. https://doi.org/10.1016/j.geoforum.2015.12.002 
Hughes, T., Lott, G.K., Poultney, M.J., Cooper, B.J., 2013. Portland Stone: A nomination for "Global Heritage Stone Resource" from the United Kingdom. Episodes 36, 221-226

Kramar, S., Bedjanič, M., Boštjan, R., Nina, Ž., Mojca, B., Ana, M., 2014. Podpeč limestone: a heritage stone from Slovenia. In: Pereira D, Marker B, Kramar S, Cooper B, Schouenborg B (eds) Global Heritage Stone: Towards International Recognition of Building and Ornamental Stones. J Geol Soc (London, UK) 407(1), 219-231. http://dx.doi. org/10.1144/SP407.2

López de Azcona, M.C., Fort González, R., Mingarro Martín, F., 2002. Conservation of the stone in Cibeles Fountain, Madrid (Spain). Materiales de construcción 52, 65-74. https://doi.org/10.3989/ mc.2002.v52.i265.345

Manríquez, H., Mansilla, P., FigueroaSterquel, R., Moreira-Muñoz, A., 2019. Geodiversity meets Biodiversity: a landscape approach for biogeocultural conservation and governance in Mediterranean central Chile. eco. mont 11 (1), 43-48. http://dx.doi.org/10.1553/eco. mont-11-1s43

Matthews, T., Grant-Smith, D., 2017. Managing ensemble scale heritage conservation in the Shandon architectural conservation area in Cork, Ireland. Cities 62, 152-158. http://dx.doi.org/10.1016/j. cities.2016.10.004

Misirlisoy, D., Günc, K., 2016. Adaptive reuse strategies for heritage buildings: A holistic approach. Sustainable Cities and Society 26, 91-98. https://doi. org/10.1016/j.scs.2016.05.017

Murru, A., Freire-Lista, D.M., Fort, R., Varas-Muriel, M.J., Meloni, P., 2018.
Evaluation of post-thermal shock effects in Carrara marble and Santa Caterina di Pittinuri limestone. Constr Build Mater 186, 1200-1211. https://doi. org/10.1016/j.conbuildmat.2018.08.034

Newsome, D., Dowling, R.K. (EDS)., 2010. Geotourism: The Tourism of Geology and Landscape. Oxford: Goodfellow Publishers.

Norum, R., Mostafanezhad, M., 2016. A chronopolitics of tourism. Geoforum 77, 157-160. https://doi.org/10.1016/j. geoforum.2016.10.015

Oria González, C., 1971. La Capilla Real de San Pedro de Alcántara, en Arenas de San Pedro (Ávila) Academia: Boletín de la Real Academia de Bellas Artes de San Fernando (33), 88

Pendlebury, J., Short, M., While, A., 2009. Urban world heritage sites and the problem of authenticity. Cities 26, 349-358. https://doi.org/10.1016/j.cities.2009.09.003

Pereira, D., Marker, B., 2016. The value of original natural stone in the context of architectural heritage. Geosciences 6, 13. https://doi.org/ 10.3390/geosciences6010013

Ponz, A., 1772-1794. Viaje de España, o Cartas en que se da noticia de las cosas más apreciables y dignas de saberse, que hay en ella Tome X, letter III. 57p

Portillo, H.L., García-Rodríguez, M., García, J.M., 2018. Itinerario didáctico, ambiental y cultural por Valdemorillo (Madrid). Observatorio Medioambiental, 21(0). https://doi.org/10.5209/OBMD.62659

Primavori, P., 2015. Carrara Marble: a nomination for 'Global Heritage Stone Resource' from Italy. J Geol Soc (London, UK) 407, 137-154. https://doi. org/10.1144/SP407.21 
Romana Lugeri, F., Farabollini, P., 2018. Discovering the Landscape by Cycling: A Geo-Touristic Experience through Italian Badlands. Geosciences 8 (8), 291. https://doi:10.3390/geosciences 8080291

Saluja, V., Anand, S., 2017. Land use and land cover change in first proposed national geopark, Varkala in Kerala, India. International Journal of Geoheritage 5(2), 33-42. https://doi.org/10.17149/ijg. j.issn.2210.3382.2017.02.003

Siegesmund, S., Török, A., 2011. Building stones. In: Siegesmund S, Snethlage R (eds) Stone in architecture-properties, durability. Springer, Berlin, Heidelberg. 11-96. https://doi.org/10.1007/978-3642-14475-2_2

Singh, R.B., Subhash, A., 2013. Geodiversity, Geographical Heritage and Geoparks in India. International Journal of Geoheritage 1(1), 10-26
Soini, K., Birkeland, I., 2014. Exploring the scientific discourse on cultural sustainability. Geoforum 51, 213-223. https:// doi.org/10.1016/j.geoforum.2013.12.001

Urbina, D., Sánchez, A., Lomhardero, M., Regueiro, M., 1997. Mármoles romanos y canteras. Zephyrus 50, 273-287

Van Oers, R., 2010. Managing cities and the historic urban landscape initiative - an introduction. In R. van Oers, and S. Haraguchi (Eds.), Managing historic cities (pp. 7-18). Paris: World Heritage Centre, UNESCO.

Zoghlami, K., Martín-Martín, J.D., GómezGras, D., Navarro, A., Parcerisa, D.M., Rosell, J.R., 2017. The building stone of the Roman city of Dougga (Tunisia): Provenance, petrophysical characterisation and durability. C R Geosci 349 (8), 369-424. https://doi.org/10.1016/j. crte.2017.09.017 
